\title{
Facilitation and Support as Factor Affecting Motivation of Market
}

\author{
Nasser Fegh-hi Farahmand ${ }^{*}$ \\ Department of Industrial Management, College of Management, Economy and Accounting, Tabriz Branch, Islamic Azad University, \\ Tabriz, Iran \\ *Corresponding author: farahmand@iaut.ac.ir
}

Received March 11, 2014; Revised March 15, 2014; Accepted March 17, 2014

\begin{abstract}
During the last decade, theoretical and empirical researches have indicated that organizational facilitation and support as a process occurs in various sites and situations, and it should not viewed from only economic-profit perspective. The importance and growth of the products and services reviewed that it is expanding globally. Furthermore, researchers believe that the primary objective of the corporate organizational facilitation and support is creation of dynamism, competitive structure and culture. Facilitation and support -management behavior in organizations regarded as a tool for organizations' growth and profitability, strategic innovation, organizational and customer- oriented changes. This article attempts to explain the facilitation and support plan management by pasterns of thinking. The importance of strategic, long-term policy and facilitation and support plan management is very clear to planners. Facilitation and support managers like to follow a similar and routine facilitation and support behavioral pattern.
\end{abstract}

Keywords: facilitation and support, factor-affecting motivation market organization, commitment organization

Cite This Article: Nasser Fegh-hi Farahmand, "Facilitation and Support as Factor Affecting Motivation of Market.” Journal of Business and Management Sciences, vol. 2, no. 1 (2014): 10-20. doi: 10.12691/jbms-2-1-2.

\section{Introduction}

Facilitation and support plan management, normally taken, as a part of facilitation and support planning, therefore also tends to run in cycles of around last years. Implementing factor affecting motivation market organization can give a competitive advantage and help foster goodwill toward facilitation and support approach. Individual organizational facilitation and support in organizations' context includes the actions of key actors at every level for creating value in the organization (Ergun et al., 2004). With the rise in the standard of living, resulting from increased factor affecting motivation market organizational productivity changes in the needs and demands of the population. Facilitation and support approach has been widely used to translate commitment organization expectation to a products and services technical attributes. Products and services have emerged as the fastest growing component of international trade. This paper proposes a commitment organization expectations method that considers factor affecting motivation market organization s information. The rise of intense competition among the domestic and global markets has revealed the crucial role of organizational facilitation and support in actualization and maintenance of competitive privilege development in the facilitation and support organizations.

\section{Factor Affecting Motivation Market Organizations}

Correctly rating the importance of every commitment organization expectation is essential for the facilitation and support process because it will largely affect the final target value of a products and services technical attributes. In today's factor affecting motivation market organizational environment, there are usually several products and services to fulfill certain functions. The success of a products and services depends not only on whether it meets the commitment organization expectations, but also on how it compares with other factor affecting motivation market organization s products and services. Most likely, factor affecting motivation market organization will quantify success in many ways. The importance of strategic, long-term policy and facilitation and support plan management is very clear to planners. Facilitation and support managers like to follow a similar and routine facilitation and support behavioral pattern. Facilitation and support plan management, normally taken, as a part of facilitation and support planning, therefore also tends to run in cycles of around last years. Implementing factor affecting motivation market organization can give a competitive advantage and help foster goodwill toward facilitation and support approach. Studies on corporate organizational facilitation and support have possessed an increasing growth. The percentage of growth of the different factor affecting 
motivation market organizational criteria in the products and services as commitment organization expectations is continuing to increase as the factor affecting motivation. Facilitation and support success is about lucrative financial gains or about building something for factor affecting motivation market organization. It is about making a difference in factor affecting motivation market organizational community, or creating the very best product or service on the market or simply doing something factor affecting motivation market organization love to do. It is not difficult to envision what factor affecting motivation market organizations want out of their facilitation and support, but how will you get there. The key to factor affecting motivation market organizational success is having a facilitation and support plan in place. Whether factor affecting motivation market organization is about to launch a start-up or factor affecting motivation market organization have been in facilitation and support for years, factor affecting motivation market organizational facilitation and support direction guided by factor affecting motivation market organizational facilitation and support plan.

\section{Factor Affecting Motivation Market Organizations}

To begin the planning process, factor affecting motivation market organization need to do some critical analysis; facilitation and support planning is about realistically forecasting where your facilitation and support is going. Therefore, the design management in the products and services is becoming increasingly important and this importance will continue to grow over this century. Factor affecting motivation market organizations are facing fundamental issues such as how to design and implement an effective quality service delivery system, which will help to establish and to retain global market share. Much of the published work on quality focuses on manufactured products and services, but managers are paying more attention to emphasizing quality in services. Making a difference in factor affecting motivation market organization or creating the very best product or service on the market or simply doing something loves to do. In practice, factor affecting motivation market organizations usually characterized by simple factor affecting motivation market organizational structures. Which facilitate rapid decision-making and often display a high degree of innovation? The management techniques and operating structures employed are one way of identifying the maturity of the factor affecting motivation market organization [25]. Therefore, factor affecting motivation market organizational capability relies in particular on coaching management skills, which rely on emotional intelligence and emphasis one-to-one, dialoguing, subordinate empowerment and mutually agreed targeting.

\section{Facilitation and Support Management}

Most likely, factor affecting motivation market organization will quantify success in many ways. It is not difficult to envision what you want out of factor affecting motivation market organizational facilitation and support, but how will factor affecting motivation market organization get there. While the definition of what constitutes a factor affecting motivation market organization varies, it generally based on the number of employees and products and services turnover. When there are cross effects between innate facilitation and support and facilitation and support experience, the variance of facilitation and support will also increase with facilitation and support tenure in absence of commitment. Facilitation and support committee with employees, suppliers and competitors have a stake and essential ingredient for success is a senior quality committee, which provides leadership in quality and stimulates cultural change. Several papers [12,70,150,157] report a positive association between variance of facilitation and support and facilitation and support tenure and explain it as a consequence of commitment. However, this evidence can explained one from commitment theory and the other from the interaction between innate and acquired abilities. Other tests $[2,16,60]$ conducted with panel data are subject to the same doubts about the true causes behind their empirical evidence. Anyhow, tactical actions steps for coupling quality with commitment organization or service receivers recovering satisfaction. An factor affecting motivation market organization's total facilitation and support efforts must begin at the very top and begin with the board of directors. The answers to these and other questions will provide valuable insights into the existing corporate culture and indicate the factor affecting motivation market organization 's readiness for adopting facilitation and support. Develop a vision or approach statement if the factor affecting motivation market organization does not have one already. The key to the initial adoption of facilitation and support is continuous communication of the vision within a comprehensive communication plan. In addition, it could happen that the proxies used for innate abilities can correlated with unobserved investments in on the facilitation and support training by workers or with other proxies of innate abilities used by employers when the facilitation and support is hired. As a high-leverage intervention, the impact of a coach on a few key individuals can drive through massive changes in a corporate setting. Factor affecting motivation market organization's with successful quality cultures start by training and educating senior management, followed by all employees that the establishment of quality teams is a top priority.

Techniques of factor affecting motivation market organization can related in part to the growing influence of the factor affecting motivation market organization $s$ philosophies. In recent years, it has expanded most notably to include simultaneous management, benchmarking and increasing emphasis on issues relating to factor affecting motivation market organization management. Clearly, the management of factor affecting motivation market organization s seeking world class status would appear to be faced with a far more complex task than was the case previously (Feghhi farahmand, 2004, 169). One of the main reasons for the inappropriate use of advanced factor affecting motivation market organization s technologies and techniques in many factor affecting motivation market organization s arises from an inadequate understanding of their production and operation problems and the integrated nature of modern 
technology. All too often, technological solutions are imposed which necessitate the factor affecting motivation market organization to engage in an factor affecting motivation market organizational metamorphosis to effectively employ them [24]. These can often produce sub optimal results. Ideally, the reverse process should occur, where the factor affecting motivation market organization progresses from a detailed understanding of its problems, which ensures that a particular technology or technique is adapted to meet the needs of the factor affecting motivation market organization [46]. This process of adaptation should also take into account the production and operation, size and workforce. Factor affecting motivation market organization needs to frame in terms of the needs of the factor affecting motivation market organization rather than the other way round.

It is a decreasing function of factor affecting motivation market and important action for organization because, for example, on the facilitation and support plan training decreases as a worker gets older. If this were the case, facilitation and support organization would get another empirical prediction. Therefore, facilitation and support find a possible alternative explanation for facilitation and support main predictions of commitment theory that can empirically tested by models of between facilitation and support dispersion. Coaching in the factor affecting motivation market organization setting provides a key component in the transformational processes towards value-driven management. Through its support for and focus on individual performance, it aims at achieving corporate factor affecting motivation market. Senior managers need coaching as the new theorists in coaching argue; coaching empowers individuals to achieve their inherent potential. Coaching makes sense as investment only if it improves the performance not only of the individual, but the factor affecting motivation market organization as well. In this sense, the word strategic becomes important. For many factor affecting motivation market organizations, becoming factor affecting motivation market does not always mean implementing the most advanced technologies; instead, its competitiveness may arise from the flexibility and skills of its workforce, or a unique market niche and factor affecting motivation market [171]. The characteristics of corporate organizational facilitation and support are newbusiness-venturing, innovativeness of products/services, innovation in the process, self-renewal, risk taking, proactive ness, and competitive privileges [6]. The information collected from sample of middle and top managers from each facilitation and support organizations through face-to-face, consultant sessions, interview, mail and e-mail about the characteristics of the organizations. A useful framework for analyzing the deficiencies of the factor affecting motivation market organization $s$ operations is to identify gaps in the production and operation that lead to inefficiencies and compare these to its own model of what constitutes world class in its field. By applying an iterative process and identifying gaps in its performance, the factor affecting motivation market organization can assess the suitability of potential solutions at a level appropriate to the requirements and resources of an factor affecting motivation market organization. The operational concept based on customer satisfaction, where the operation of quality management system is customer-oriented and aims at improving of bellow items:

1. Customer satisfaction by commitment organization' needs and expectations;

2. Clear management responsibility by communication,

3. Resource management for product realization process,

4. Structure of measuring for monitoring customer satisfaction.

The purpose of factor affecting motivation market organizational facilitation and support is capable by with description of factor affecting motivation market organizational products and services in facilitation and support legal structure.

All above-mentioned items proposed based on overall performance of the facilitation and support and requires enterprises evaluate performance from the perspective of commitment organization. For this reason, facilitation and support plan management give a overview of factor affecting motivation market organizational facilitation and support where factor affecting motivation market organization have been, where you are now, and where factor affecting motivation market organization is going in the future. The central approach of factor affecting organization activities under the enlightenment model is to raise the facilitation and support level of the factor affecting motivation market organization. The starting point in the facilitation and support plan management is the assumption of facilitation and support.

The corporate organizational facilitation and support may considered as a system, which enables individuals to employ the creative processes that offer them opportunity to apply or invent the technologies that can be purposeful and planned in terms of the innovative activities' level (Echols \& Neck, 1998). The characteristics were such as size and industry; about personal characteristics of managers, such as age, formal education, years in the current facilitation and support; and about facilitation and support positions, such as hierarchical level and functional area. The formal education and experience improve the information available to organizations about managers' ability and that there will be better matching between employees' abilities and facilitation and support over time. Conditional facilitation and support dispersion increases with formal education and work experience when the facilitation and support equation does not control for facilitation and support positions. Furthermore, this conditional facilitation and support dispersion is greater for those managers who, monitoring for age, have more years of education that this result interpreted because of the signaling properties of education [91] and education could used to signal innate ability [174]. Facilitation and support organizations should expect higher facilitation and support dispersion for more educated workers if higher education is a more effective way of signaling hidden abilities than work experience.

Otherwise, facilitation and support management would prefer to take a facilitation and support earlier on in life so that employers could learn about their hidden abilities from work experience. Further, in depth work needed to sort out these alternative explanations of the empirical evidence. Additionally, it viewed as a good predictor of the small firms' progress in hostile environments. 
Organizational facilitation and support involves uncommon events and recognition of entrepreneurial firms. All managers within a hierarchical position will have an estimated ability at the time of promoted to the facilitation and support equal to that demanded for that position. However, estimated ability at the time of promotion may vary in terms of precision if hidden ability garnered from the information available about each manager and this information varies between him and her. This implies that conditional facilitation and support variance within the facilitation and support will increase with facilitation and support tenure commitment continues, and facilitation and support variance precision will be lower or higher for managers with a more formal education and more work experience at the time of the promotion, because there is more information available to estimate their ability. The corporate organizational facilitation and support is a process that creates products and services or innovative processes by establishing the entrepreneurial culture in an organization (Fry, 1993). As a part of successful organizations, the corporate organizational facilitation and support is associated with the large organizations' growth. Miller and Frizen (1982) and Kandwalla (1977) made use of risk taking, proactive ness, and innovation for the purpose of conceptualization and organizational facilitation and support measurement. In the most of other research studies (Covin and Covin 1990; Covin and Slevin 1991; Lumpkin and Dess 1996; Birkinshaw 1999; Covin and Miles 1999; PiItaway 2001; Dess, Treland, Floyd, Janney and Lane 2003) corporate organizational facilitation and support has been introduced as concept embracing creativeness, risk taking, innovation, and competitive aggressiveness (Aktan and Bulut, 2008). As facilitation and support variation increases with facilitation and support tenure $[12,150]$, but the multivariate analysis of the error variance also led us to verify that, it decreases with formal education and work experience prior to the current facilitation and support. These results cannot be explained by conventional human capital models and provide a more robust test of commitment. These components increase the performance of firms, the correspondence between organization and environment, and the speed of strategic reaction to environmental changes. There are, however, other possible explanations for the results highlighted in the theory section, which come from facilitation and support theory. For example, it may be that the return on investment in facilitation and support training decreases over time in situations where innate ability and acquired human capital interact in determining the workers' productivity. In that case, facilitation and support dispersion expected to increase per additional year of facilitation and support at a lower rate than per year of general experience.

To begin the planning process, factor affecting motivation market organization will need to do some critical analysis; facilitation and support planning is about realistically forecasting where factor affecting motivation market organizational facilitation and support is going. Optimal utilization of facilitation and support plan is advancing at a very fast pace, and obsolescence of physical facilitation and support infrastructure of skills and competence, take place rapidly.
Strengthening of facilitation and support plan as a major initiative to modernize the infrastructure in organization will be undertaken. Mechanisms for facilitation and support plan for setting up of more efficient funding mechanisms examined, either by creating new structures or by strengthening or restructuring the existing ones, for promotion of basic research in facilitation and support plan. Personnel of facilitation and support plan as facilitation and support technologists, while being large in absolute numbers is not commensurate with the requirements in facilitation and support and when measured on a per capita basis.

Technology development of facilitation and support plan as a strong base of facilitation and support plan provides a crucial foundation. Knowledge of facilitation and support plan would be further developed and harnessed for the purpose of facilitation and support generation. Facilitation and support has an important role in any general management to address the problems of management of the impacts of natural hazards. The introduction of facilitation and support positions to explain differences in managerial facilitation and support could make the information about the characteristics of the manager irrelevant in determining facilitation and support. After all, holding a particular facilitation and support position implies having the ability required for the facilitation and support. Monitoring for facilitation and support substantially reduces the effects of education and general work experience on facilitation and support. Although facilitation and support heterogeneity and differences in factor affecting motivation market organization cannot ruled out as potential explanations, the insurance effects predicted by the commitment models [91] may be an alternative explanation for the observed positive effect of experience and education in facilitation and support after monitoring for factor affecting motivation market organization. Another important result is that, monitoring for facilitation and support, the effect of facilitation and support tenure on facilitation and support becomes statistically significant and positive. Facilitation and support managers acquire specific human capital with on the facilitation and support experience [183], which can only be properly evaluated when facilitation and support are incorporated into the model.

\section{Facilitation and Support for Factor Affecting Motivation Market}

There is evidence in the data that facilitation and support tenure is higher for lower hierarchical positions than for higher ones. Facilitation and support tenure is associated with lower estimated innate ability, because those managers whose ability believed to be higher promoted faster to higher hierarchical positions. Promotion to a higher hierarchical position may be the result of an optimal assignment of abilities to facilitation and support or the consequence [135] of the incentives established by the organizations, as in tournament models. The observed convexity between hierarchical position and facilitation and support, together with the fact that facilitation and support has more explanatory power for differences in facilitation and support than do facilitation 
and support variables interpreted as evidence of tournament-type explanations for the facilitation and support differences between hierarchical positions.

A facilitation and support -management manager is a person who takes all the three steps simultaneously, whereas a successful facilitation and support manager is the one who does the stages to gain the title of facilitation and support manager. Organizational facilitation and support accompanies venturous innovation while people are escaping from its risk. Innovativeness is the step of technology development process. Commitment will continue in the new facilitation and support, but the information content of this commitment expected to be lower for managers who started the facilitation and support with more precision in their estimated abilities. The survival in the market is the outcome of these three phenomena, which can be used exchange ably. Innovativeness is an environmental requirement in the field of organizational facilitation and support, which refers to the capability of a corporation for creation of a new product and successful launch of it to the market (Avlonitis and Salavou, 2007). Striving for innovativeness brings about a lasting value which is part of the facilitation and support ' nature [57]. The concept of innovative products has attracted the attention of some experts and researchers (Avlonitis and Salavou, 2007: 567). Deshpande et al (1993) consider innovativeness as one of the essential competitive instruments for achieving success and long-term survival of facilitation and support organizations.

The increase of attention to innovativeness can be a key factor in the success of enduring competitive privilege of facilitation and support organizations. The relative importance rating obtained from the traditional rating methods, such as commitment organization expectations survey, expert opinion, analytic hierarchy process method. The present point method is very straightforward, and there are many papers discussing it in facilitation and support approach [126,163]. Nevertheless, this explanation ignores possible differences in productivity between hierarchical levels due differences in information about innate ability not captured by such observable variables as education and experience.

Facilitation and support approach has been widely used as a multi functional design tool to translate commitment organization expectations to a products and services technical attributes.

Facilitation and support process with analytic hierarchy process proposed used in rating commitment organization expectation $\mathrm{s}$ and the sensitivity $[1,8,10,115]$ of the commitment organization voice in facilitation and support approach analyzed [139]. However, commitment organization opinions are often vague and contain ambiguity and multiple meanings [76,120]. From the commitment organization perspective, all methods have the same characteristics that coordinated with the basic spirit of facilitation and support approach, commitment organization driven design. The facilitation and support organizations are order to keep pace with technology, markets, and flow and even rebuild them. The facilitation and support is corporate culture, which persuades the staff for innovativeness and gaining an organizational perception of developing new products or processes.

\section{Facilitation and Support Factor Affecting Motivation of Market Organization Success}

Correctly rating the importance of every commitment organization expectation is essential to the facilitation and support process because it will largely affect the final target value of a products and services technical attributes. Therefore, it is important to integrate factor-affecting motivation into products and services design and development. The gradual facilitation and support strategies are the outcome of a continuously improving process. Put differently, facilitation and support could improve and develop the knowledge and the process. Radical facilitation and support strategies are a completely new phenomenon, which can obtain through investigation and development in the industrial, investigative laboratories. Factor affecting motivation market organizations compete with the quality level of their products and services that managers cannot manage factor affecting motivation market organizational competition, will have problems surviving. Facilitation and support managers promoted to higher facilitation and support for factor affecting motivation market organization, but these increases are lower than the differences in average facilitation and support between levels [12]. Managers who have held their positions for a longer period will have acquired more facilitation and support approach, and on the facilitation and support acquisition increases with the innate ability of the managers [83]. However, in today, several products and services can satisfy the commitment organization that simply meeting commitment organization expectation s cannot guarantee a successful products and services. Factor affecting motivation market organization s must consider their positions to make sure that their products and services would not lag behind other factor affecting motivation market organization s products and services. The key to factor affecting motivation market organization success is having a facilitation and support plan in place. Whether factor affecting motivation market organization is about to launch a start-up or factor affecting motivation market organization have been in facilitation and support for years, factor affecting motivation market organizational facilitation and support ' direction guided by facilitation and support plan. In spite of this general awareness, such long-term facilitation and support, strategic-level planning of facilitation and support has been lacking in factor affecting motivation market organization. A central motivation for this has been the public uneasiness towards many of the applications of gene factor affecting motivation market organization $\mathrm{s}$ technology, as well as the general distrust of the public towards officials, scientists and representatives of factor affecting motivation market organization $s$ in the management of risks.

In order to be able to do this successfully, the products and services of factor affecting motivation market organization has to view its facilitation and support and its customer relationships from a expectation perspective. There are always relationships between products and services of factor affecting motivation market organization and its commitment organization expectations. The key 
issue is whether the factor affecting motivation market organization wants to make use of these relationships in the way it manages commitment organization expectations or not, and whether a given commitment organization wants to be an actively managed relationship with the products and services provider, or not.

Forever, factor affecting motivation market organization should set up definite policy and target and the degree of customer satisfaction should clarify. In according to facilitation and support target, factor affecting motivation market organization should plan facilitation and support system and relative structure, authority and responsibility control, operation process and standards, in order to ensure comply with plan and achieve enterprise facilitation and support target. In addition, factor affecting motivation market organization should carry out communicating harmonization, encourage staffs involvement and full commitment to customer satisfaction, also managers' decision-making should comply with the quality facilitation and support and target as the maximum guidance principle. Factor affecting motivation market organization must provide all required resources, according to the plan then produce and sell products to commitment organization. After the adjustment and improvement, factor affecting motivation market organization should re- measure customer expectations, to ensure the improvement scheme is proper and effective. Facilitation and support is definable at least from two perspectives;

1). What the facilitation and support organizations intends to do? From this perspective, facilitation and support is a comprehensive plan for achieving an organization's objectives and performing its own approach, with the underlying theory that the management should formulated in the framework of a process.

2 ). What the facilitation and support organizations does finally? From this perspective, facilitation and support is the pattern of the organization's reactions to its environment over time, with the assumption that the management developed through insight and inspiration.

Facilitation and support as a pattern or a plan that integrates the objectives, policies, and action sequences of an organization into a cohesive whole if well formulated, it can be useful in allocation of an organization's resources into a unique and viable posture based on its relative internal competencies and shortcomings, predicted environmental changes, and intelligent rivals' contingent moves. Facilitation and support as the large-scale and future-oriented plans for interaction with the competitive environment to optimize achievement of an organization's objectives, in other words, a game plan that although does not detail all of the future needs associated with people, finances, or materials, it provides a framework for decision making.

Facilitation and support with the determination of an organization's major and long-term goals, can select of actions, and allocation of the required resources for achieving the goals.

If managers who need less work experience to reach their current hierarchical position are, also those with higher innate abilities the marginal return from one year of facilitation and support tenure should decrease with the age of the manager. The marginal return of facilitation and support tenure decreases with the age of the manager, but cannot rule out the alternative explanation that investment in on the facilitation and support training, as managers get older. The evidence suggests that better assignment of managers to facilitation and support positions because of commitment competes with incentive/tournament reasons for explaining the promotion of managers to higher- level facilitation and support, something that often ignored in previous empirical tests of tournament models [43,58]. Implementing good environmental and social practices is good facilitation and support can give factor affecting motivation market organization a competitive advantage and help foster goodwill toward factor affecting motivation market organizational facilitation and support. Factor affecting motivation market organization should discuss ways in which factor affecting motivation market organizational facilitation and support honors ethical values and respects people, factor affecting motivation market organizational community, and the environment. Facilitation and support as factor affecting motivation market and important action for organization and target management structure derive management system requirements in facilitation and support plan management. Factor affecting motivation market organization should set up definite policy and target and the degree of customer satisfaction should clarify. According to quality target, enterprises should plan total management system structure, authority and responsibility control, operation process, in order to ensure comply with plan and achieve enterprise quality target. Factor affecting motivation market organization should carry out communicating harmonization, encourage staffs involvement and full commitment to customer satisfaction managers' decisionmaking should comply with the facilitation and support policy and target as the maximum guidance principle. Factor affecting motivation market organization s provide all required resources, according to the plan then produce and sell products to commitment organization.

Facilitation and support feedbacks as factor affecting motivation market organization aim at commitment organization after sales feedback must verify the degree of customer satisfaction. If it does not achieve the expected degree of satisfaction, the manager should identify the cause and work out an improvement scheme to enhance customer satisfaction. Rectification and preventing methods can used through adjusting original quality policy and target, quality rules, communication, training, resources and operation process, etc. After the adjustment and improvement, enterprises should re-measure customer satisfaction, to ensure the improvement scheme is proper and effective. Factor affecting motivation market organization should provide commitment organization' feedback information to management for inspection and verify appropriateness and effectiveness of the definition of quality policy and target, quality scheme and operation methods.

\section{Finding}

Relevant certifications, such as fair-trade certification, organic certification, or leadership in energy and environmental design certification. Environmental programs and resources could influence factor affecting motivation market organizational facilitation and support, 
from greening your facilitation and support to finding funding to become environmentally efficient. In order to stay competitive in today's market, factor affecting motivation market organization might want to consider where corporate social responsibility fits into your operations. There is no consensus upon the sense of innovativeness. This concept defined as creation of novelty, approach of a behavior or belief that is novel for the organization. A number of the researchers (Kleinschmidt \& Cooper, 1991; Olsen \& Sallis 2006; Olson, Walker, \& Ruekert, 1995) describe innovativeness as degree of novelty that is in connection with corporate and outside world. Although introducing a facilitation and support is necessary, it is not sufficient for starting innovation. The innovative product or service should outrival the competitors in the market (Tajeddini, 2010). Factor affecting motivation market organizations have witnessed what has happened to manufacturers that allowed the quality of their products and services to deteriorate. They also recognize that providing highquality products and services to keep a customer is much less expensive than acquiring a new one. Products and services quality has a major effect on the ability to attract and retain both commitment organization and employees, and it contributes directly to superior productivity. For this reason, implementing good environmental and social practices is good facilitation and support can give factor affecting motivation market organization a competitive advantage and help foster goodwill toward factor affecting motivation market organizational facilitation and support. Factor affecting motivation market organization $\mathrm{s}$ are facing fundamental issues such as how to design and implement an effective quality service delivery system, which will help to establish and to retain global market share. Much of the published work on quality focuses on manufactured products and services, but managers are paying more attention to emphasizing quality in services. The reason is the general perception that products and services quality is not good.

Therefore, improving quality is becoming a major objective in factor affecting motivation market organization s throughout the world. The recognition that survival much less growth in the factor affecting motivation market is a function of quality led to the increasing emphasis on facilitation and support. Factor affecting motivation market organization should discuss ways in which factor affecting motivation market organizational facilitation and support honors ethical values and respects people, factor affecting motivation market organizational community, and the environment.

\section{Conclusions}

The empirical results that the assignment of a manager to particular facilitation and support reveals the information employers have about the facilitation and support hidden ability at the time of the assignment. The fact that commitment continues after the assignment suggests that the assignment made with imperfect information. If promotions based on the estimated facilitation and support ability of the individual managers, workers assigned to a given hierarchical level at the same moment in time will have similar expected abilities, albeit assessed with different levels of precision. Facilitation and support regarded as one of the prerequisites of success and survival of the facilitation and support organizations and classified into facilitation and support plan and facilitation and support in economy and business.

The empirical prediction coming from this is that within-facilitation and support facilitation and support dispersion will be lower among that facilitation and support for which the assessment of their ability was more imprecise at the time of the promotion. If facilitation and support experience and formal education improve the precision of the assessment, then within facilitation and support facilitation and support dispersion should decrease with experience and education, whereas between facilitation and support s management dispersion expected to increase with these two variables. This distinction, new in the literature formalized and empirically supported by a large sample of data for managerial facilitation and support. Factor affecting motivation market organization competes with the quality level of their products and services, which cannot manage factor affecting motivation market organization s competition, will have problems surviving. In order to be able to do this successfully, the products and services factor affecting motivation market organization has to view its facilitation and support and its customer relationships from a products and services quality improvement perspective. There are always relationships between a products and services and its commitment organization expectations. The key issue is whether the firm wants to make use of these relationships in the way it manages commitment organization expectations or not, and whether a given commitment organization wants to be an actively managed relationship with the products and services provider, or not. In this paper, the importance and growth of the products and services sector reviewed. The products and services are expanding globally. The percentage of growth of the different economic criteria in the products and services is continuing to increase as the manufacturing base declines. Therefore, design management in the products and services is becoming increasingly important and this importance will continue to grow over this century.

\section{References}

[1] Akao, Y. Akao, (1990). Quality function deployment: integrating customer requirements into product design, Productivity Press, Cambridge.

[2] Altonji, J.G. and C.R. Pierret (2001). Employer Commitment and Statistical Discrimination, the Quarterly Journal of Economics, 116.

[3] Andersson, F. (2002). Career Concerns, Contracts, and Effort Distortions, Journal of Labor Economics, 20.

[4] Ansoff, H. T. (1965). Corporate Management: An analytic approach to facilitation and support policy for growth and expansion. New York: McGraw-Hill.

[5] Anton, J. Perkins, D. Feinberg, R.A. (1998). Voice of the Customer, Bard Press.

[6] Antoncic B and Hisrich R.D. (2004). “Corporate factor affecting motivation market organizational facilitation and support contingencies and factor affecting motivation market organizational wealth creation”, Journal of Management Development, Vol. 23, No. No. (6). pp. 518-550.

[7] Arash Shahin (2009). Growth of the service sector: a demand for the use of quality improvement techniques to increase service quality, The Third International Conference on Quality Management, University of Newcastle. 
[8] Armacost et al. (1994). An AHP framework for prioritizing customer requirements, ITE Transactions. No 16.

[9] Armacost, P.J. Compo nation, M.A. Mullens and W.W. Swart (1994). An AHP framework for prioritizing customer requirements in QFD: an industrialized housing application, ITE Transactions 26 (4), pp. 72-79.

[10] Aswad, A. (1989). Quality function deployment: a systems approach. In Proceedings of the 1989 ITE integrated systems conference (pp. 27-32). Norcross, GA.

[11] Auriol, E., F. Guido, Pechlivanos (2002). Career Concerns in Teams, Journal of Labor Economics, 20.

[12] Baker, G., Gibbs, B. Holmstrom (1994). The Wage Policy of a Factor affecting motivation market organization, The Quarterly Journal of Economics, 92.

[13] Barkham, R, (1996). The Determinants of small Factor affecting motivation market organization Growth, London, Jessica Kingsley.

[14] Baron, R. M. and Kenny, D. A. (1986). the distinction in social research, Journal of Personality and Social Psychology, 51.

[15] Barringer, Bruce R and Bluedorn, Allen C. (1999). The Relationship between Corporate Factor affecting motivation market organizational facilitation and support And Strategic Management, Strategic Management Journal, Strat. Mgmt. J., 20: 421-444.

[16] Bauer, T.K. and J.P. Haisken -De New (2001). Employer Commitment, Labor Economics, 8.

[17] Baysinger, B. D., Kosnik, R. and Turk, T. A. (1991). Effects ownership structure, Academy of Management Journal, 34.

[18] Becker, G.S. (1964). Human Capital, New York: Columbia University Press.

[19] Belsey, D. A., Kuh, A. and Welsch, M. E. (1980). Regression Diagnostics, New York: John Wiley.

[20] Bernhardt, D. (1995). Strategic Promotion and Facilitation and support, Review of Economic Studies, 62.

[21] Bethel, J. E. and Liebeskind, J. (1993). The effects of corporate ownership on corporate, Strategic Management Journal, 14.

[22] Blaug, M. (1976). the Empirical Status of Human Capital Theory, Journal of Economic Literature, 14.

[23] Blaug, M. (1992). the Economic Value of Education, Edward Elgar Publishing Limited.

[24] Bolton, B and Thompson J. (2003). Entrepreneurs and Technique, London: Butterworth Heinemann.

[25] Bridge, S. O'Neill, K and Cormier S. (2002). Understanding Enterprise, London: Macmillan Facilitation and support.

[26] Brunette, Ken, (2001). The Handbook of Key Customer Relationship Management, prentice Hall.

[27] Bygrave, W., The Portable MBA in Factor affecting motivation market organizational facilitation and support, N.Y: John Wiley and Sons Ashmos, D.P. and Duchon, D. (2000). spirituality at work: definitions, measures, assumptions, and validity clamims, paper presented at the academy of management, Toronto.

[28] C. Temponi, J. Yen and W.A. Tlao (1999). House of quality: a fuzzy logic-based requirements analysis, European Journal of Operational Research 117 (2), pp. 340-354.

[29] C.K. Kwong and H. Bai (2002). a fuzzy AHP approach to the determination of importance weights of customer requirements in quality function deployment, Journal of Intelligent Manufacturing 13 (5), pp. 367-377.

[30] Cameron Kim S, (1996). a study of factor affecting motivation market organizational effectiveness and its predictors, Management science review.

[31] Cameron, K. S. (1994). Strategies for successful factor affecting motivation market organizational downsizing, Human Resource Management, 33.

[32] Cappelli, P. and W.F. Cascio (1991). Why Some Jobs Command Wage Premiums, Academy of Management Journal, 34.

[33] Capron, L. (1999). the long term performance of horizontal commitment, Strategic Management Journal, 20.

[34] Chan and Wu, (2002). Quality function deployment, European Journal of Operational Research, no 153.

[35] Chan and Wu, (2005). A systematic approach to quality function deployment, Omega 33.

[36] Chan et al., (1999). Customer needs in quality function deployment by fuzzy, Journal of Production, no 37.

[37] Chandler Alfred Jr, (1992). Management and structure, Cambridge mass, M.T.T press.

[38] Chevalier, J. and G. Ellison (1999). Career Concerns of Mutual Fund Managers, the Quarterly Journal of Economics, 114.
[39] Cohen, L. (1999). Quality function deployment, Addison Wesley, MassachuseIts.

[40] Colin Carnal Susan (1988). Management principles policy, TCSA Cambridge.

[41] Collis, D. J. (1998). creating competitive advantage, Harvard Facilitation and support Review, 76.

[42] Collis, D. J. and Montgomery, C. A. (1995). Competing on resources, Harvard Facilitation and support Review, July- August, 73.

[43] Conyon, M.J., T.P. Simon, and V.S. Graham (2001). Corporate Tournaments and Executive Facilitation and support, Strategic Management Journal, 22.

[44] Cornwall, J. R., and Perlman, B. (1990). Corporate factor affecting motivation market organizational facilitation and support. Homewood, TL: 17 Boston -Trvin.

[45] Deakins, D, and Freel, M. (1998). entrepreneurial commitment and the Growth process in sme s, the commitment organization: 144-55 white rose centre for factor affecting motivation market in facilitation and support and commitment of enterprise.

[46] Curran, J. and Blackburn, R. (2002). Facilitation and support planning and Local Economic Networks, London: Paul Chapman.

[47] D.G. Ullmand (1992). the mechanical design process, McGrawHill, New York.

[48] David, F. A. (2000). Strategic management (Translated by A. Parsian and M. Araabi). Tehran: Cultural Researches Office, Vol. 1 , 4th edition.

[49] DeGroot, M.H. (1970). Optimal Statistical Decisions, New York: McGraw-Hill.

[50] Denison Daniel R, (1995). corporate culture and factor affecting motivation market organizational effectiveness, New York, John wiles and sons.

[51] Dimitratos P et al. (2004). "The relationship between factor affecting motivation market organizational facilitation and support and international performance: the importance of domestic environment”, International Facilitation and support Review, Vol. 13, pp. 19-41.

[52] E.E. Karsak (2004). Fuzzy multiple objective programming framework to prioritize design requirements in quality function deployment, Computers and Industrial Management 47, pp. 149163.

[53] E.E. Karsak, S. Sozer and S.E. Alptekin (2002). Product planning in quality function deployment using a combined analytic network process and goal programming approach, Computers and Industrial Management 44 (1), pp. 171-190.

[54] E.S. Ho, Y.J. Lai and S.T. Chang (1999). an integrated group decision-making approach to quality function deployment, ITE Transactions 31, pp. 553-567.

[55] Enrahimp-pour, H., Khalili, H., and Habibian, S. (2011). The investigation of relationship between strategic management and factor affecting motivation market organizational facilitation and support. Management Researches, No. 11.

[56] Entrialgo $\mathrm{M}$ et al. (2000). "Linking factor affecting motivation market organizational facilitation and support and strategic management: evidence from Spanish SMEs”, Technovation, Vol. 20, pp. 427-436.

[57] Ergün Ercan et al. (2004). "Connecting The Link Between Corporate Factor affecting motivation market organizational facilitation and support And Innovative Performance”, Global Facilitation and support and Technology Association Annual Conference Proceedings Book, pp. 259-265, July, Cape Town.

[58] Eriksson, T. (1999). Executive Facilitation and support and Tournament Theory, Journal of Labor Economics, 17.

[59] Evans and Lindsay, (2002). Management and control of quality, Singapore, Thomson Commitment.

[60] Farber, H.S. and R. Gibbons (1996). Commitment and Wage Dynamics, the Quarterly Journal of Economics, 111.

[61] Feghhi Farahmand, Nasser (2001). Executive Management Process, Tslamic Azad University, Tabriz Branch, Tran, pp 109203.

[62] Feghhi Farahmand, Nasser (2003). Permanent Management of Factor affecting motivation market organization, First edition, Frouzesh Publication, Tabriz, Tran, pp 70-83.

[63] Feghhi Farahmand, Nasser (2003). Strategic Structure of Factor affecting motivation market organization Management Process, Forth edition, Islamic Azad University, Tabriz Branch, Tran, pp 110-125. 
[64] Feghhi Farahmand, Nasser (2005). Strategic Management of Factor affecting motivation market organization, First edition, Frouzesh Publication, Tabriz, Tran, pp 19.

[65] Feghhi Farahmand, Nasser (2009). Factor affecting motivation market organization Strategic Plan compilation, First edition, Frouzesh Publication, Tabriz, Tran, pp 74-314.

[66] Feghhi farahmand, Nasser (2011). Active and Dynamic Management of Factor affecting motivation market organization, Second edition, Frouzesh Publication, Tabriz, Tran, pp 87-190.

[67] Feghhi Farahmand, Nasser (2011 a). Technology Management of Factor affecting motivation market organization, Second edition, Frouzesh Publication, Tabriz, Tran, pp 11-198.

[68] FTB (1998). Uusinta tietoa suomalaisten asenteista biotekniikkaan, FTB, Suomen Bioteollisuus.

[69] Finkelstein, S. (1992). Power in top management teams, measurement and validation, Academy of Management Journal, 35.

[70] Foster, A.D. and M.R. Rosenzweig (1993). Information Commitment, and Wage Rates in Low-Income, the Journal of Human Resources, 28.

[71] Frewer, L., Rowe, G., Marsh, R. and Reynolds, C. (2001). Public Participation Methods: Evolving and Operational sing an Evaluation Framework. UK Department of Health.

[72] Fry, L. W., Vittuci, S., and Cedillo, M. (2005). Spiritual leadership and army transformation: Theory measurement, and establishing a baseline, The Leadership Quarterly 16, 835-862.

[73] Fry, L.W. (2003) toward a theory of spiritual leadership, The Leadership Quarterly, Vol. 14 pp. 693-727.

[74] Fry, L.W. and Matherly, L.L. (2006). Spiritual Leadership and Factor affecting motivation market organizational Performance: An Exploratory Study, Tarleton State University Central Texas.

[75] Fuller, S. (2000). The Governance of Science: Tdeology and the Future of the Open Society. Buckingham-Philadelphia, Open University Press.

[76] Fung et al., (1998). Customer requirement analysis, International Journal of Production, no 38.

[77] Fung et al., (2006). Quality function deployment under uncertainties, Fuzzy Systems, no 157.

[78] Garicano, L. (2000). Hierarchies and the Factor affecting motivation market organization of Knowledge in Production, Journal of Political Economy, 108.

[79] Garvin, D.A., (1987). Competing on the eight dimensions of quality. Harvard Bus. Rev., 65: 101-109.

[80] Gerhart, B. and G. Milkovich (1990). Factor affecting motivation market organizational Differences in Managerial Facilitation and support, Academy of Management Journal, 33.

[81] Gerwin, D., (1993). Manufacturing flexibility strategic perspective. Manage. Sci., 39: 395-410.

[82] Gibbons, R. and K. Murphy (1992). Optimal Incentives Contracts in the Presence of Career Concerns, Journal of Political Economy, 100.

[83] Gibbons, R., and M. Waldman (1999). A Theory of Wage and Promotion Dynamics, the Quarterly Journal of Economics, 114.

[84] Gibbs, P. A. (1993). Determinants of corporate restructuring, Strategic Management Journal, 14.

[85] Greene, W. H. (2000). Econometric Analysis, Cliffs, NJ: Prentice Hall.

[86] Greene, W.H. (1998). Econometric Analysis, Prentice-Hall International Limited.

[87] Greenwald, B.C. (1986). Adverse Selection in the Labour Market, Review of Economic Studies, 53.

[88] Griffin and Hauser, (1993). the voice of the customer, Marketing Science, no 12.

[89] Gustafsson, A., and Gustafsson, N. (1994). Exceeding customer expectations. In Proceedings of the sixth symposium on quality function deployment (pp. 52-57). Novi, MT.

[90] Hamel, G. and C. K. Prahalad, (1994). Competing for the Future. Harvard Facilitation and support School, Boston, London.

[91] Harris, M. and B. Holmstrom (1982). A Theory of Wage Dynamics, Review of Economic Studies, 49.

[92] Harvey, A. (1976). estimating Regression Models with Multiplicative Heteroskedasticity, Econometrica, 44.

[93] Haunschild, P. R. (1994). How much is that factor affecting motivation market organization worth? Administrative Science Quarterly, 39.
[94] Hauser and Clausing, J.R. Hauser and D. Clausing, (1996) the house of quality, TEEE Management Review 24 (1) (1996), pp. 24-32.

[95] Hayes R. and Clark K, (2003). why some factories are more productive than others, Harvard Facilitation and support Review.

[96] Haynes, M., Thompson, S. and Wright, M. (2002). Factor affecting motivation market organization performance, The Journal of Industrial Economics, 1.

[97] HiIt, M. A., Bierman, L., Uhlenbruck, K. and Shimizu, K. (2006). Resources, Academy of Management Journal, 49.

[98] Ho et al., (1999). an integrated group decision making approach to QFD, ITE Transactions, and no 31.

[99] Holmstrom, B. (1982). Managerial Incentive Schemes, Reedited in Review of Economic Studies, 66.

[100] Hong, H. and J.D. Kubik (2003). Analyzing the Analysts, Journal of Finance, 58.

[101] http://www.canadafacilitation and support. ca/ eng/125/141/

[102] http://www.canadafacilitation and support. ca/ eng/145/146/

[103] http://www.canadafacilitation and support. ca/ eng/86/

[104] http://www.canadafacilitation and support. ca/eng/87/187/

[105] Treland R. Duane, Covin Jeffrey G. and Kuratko Donald F. (2009) Conceptualizing Corporate Factor affecting motivation market organizational facilitation and support, Baylor University, Factor affecting motivation market organizational facilitation and support Theory and Practice, pp. 1042-2587.

[106] Trwin, A. (1995). Citizen Science. A Study of People, Expertise and Sustainable Development. London and New York, Rout ledge.

[107] Trwin, A. and Wynne, B. (1996). Introduction. Misunderstanding Science? The Public Reconstruction of Science and Technology. Cambridge, Cambridge University Press: 1-17.

[108] Trwin, A. and Wynne, B., Eds. (1996). Misunderstanding Science? The Public Reconstruction of Science and Technology. Cambridge, Cambridge University Press.

[109] J. Wang (1999). Fuzzy outranking approach to prioritize design requirements in quality function deployment, International Journal of Production Research 37 (4), pp. 899-916.

[110] J.R. Evans and W.M. Lindsay (2002). Management and control of quality (5th ed.), Thomson Commitment, Singapore.

[111] J.R. Hauser and D. Clausing (1988). the house of quality, Harvard Facilitation and support Review, pp. 63-73.

[112] Jagdish, N. (2001). Customer Relationship Management: Concept, Tools, Applications, McGraw Hill.

[113] Johnson, M.D. Gustafsson, A. (2000). Improving customer satisfaction, Jossey Bass Press.

[114] Joss, S. and Durant, J., Eds. (1995). Public Participation in Science - The Role of Consensus Conferences in Europe. London, Science Museum with the Support of the European Comapproachs Directorate General XIT.

[115] Karsak et al., (2002). Product planning in quality function deployment, Industrial Management, no 44.

[116] Karsak, E., (2004). Fuzzy multiple objective programming in qfd, Industrial Management, no 47

[117] Kaufmann and Gupta, (1985). Introduction to fuzzy arithmetic Van No strand Reinhold, New York.

[118] Kendall st., friezes Ja., steeples Jo, etal. (2004). Flexibility program, Journal of clinical management.

[119] Khanka, S (2003). Entrepreneurial Development, New Delhi: Chandan Company ltd.

[120] Khoo and Ho, L.P., (1996). Framework of a fuzzy QFD system, International Journal of Production Research, no 34.

[121] Klüver, L., Nentwich, M., Peissl, W., Torgersen, H., Gloede, F., Hennen, L., Eijndhoven, J. v., Est, R. v., Joss, S. and Bellucci, S. (2000). European Participatory Technology Assessment. Participatory Methods in Technology Assessment and Technology Decision-Making. Copenhagen, the Danish Board of Technology.

[122] Koratco, D. Of, and Richard, M. H. (2004). Current view on factor affecting motivation market organizational facilitation and support (Translated by E. A. Mehrabi, and Tabraei, M.). Mashhad: Ferdosi University of Mashhad Publications, 1st edition.

[123] Kotha, Suresh (2010). spillovers, spill-ins and strategice entrepreneurship: America's first commercial jet airplane and boeing $\mathrm{s}$ ascendancy in commercial aviating, Strategic Factor affecting motivation market organizational facilitation and support Journal, J., 4: 284-306.

[124] Kuwahara, T., (1997). Technology Foresight in Japan: a New Approach in Methodology and Analysis. Technology Foresight, NSTDA, Bangkok, p. 87-93. 
[125] Kwong and Bai, C.K., (2002). A fuzzy AHP approach in QFD, Journal of Manufacturing, no 13.

[126] Cohen (1995). Quality function deployment: How to make QFD work for you, Addison-Wesley, Massachusetts.

[127] L.H. Chen and M.C. Weng (2006). an evaluation approach to management design in QFD processes using fuzzy goal programming models, European Journal of Operational Research 172 (1), pp. 230-248.

[128] L.K. Chan and M.L. Wu (2002). Quality function deployment: A literature review, European Journal of Operational Research 143, pp. 463-497.

[129] L.K. Chan and M.L. Wu (2005). a systematic approach to quality function deployment with a full illustrative example, Omega 33 (2), pp. 119-139.

[130] L.K. Chan, H.P. Kao, A. Ng and M.L. Wu (1999). Rating the importance of customer needs in quality function deployment by fuzzy and entropy methods, International Journal of Production Research 37 (11), pp. 2499-2518.

[131] L.P. Khoo and N.C. Ho (1996). Framework of a fuzzy quality function deployment system, International Journal of Production Research 34 (2), pp. 299-311.

[132] L.P. Sullivan (1986). Quality function deployment, Quality Progress 19, pp. 39-50.

[133] L.V. Vanegas and A.W. Labib (2001). A fuzzy quality function deployment (FQFD) model for driving optimum targets, International Journal of Production research 39 (1), pp. 99-120.

[134] Lai et al., Y.J. Lai, E.S. Ho and S.T. Chang, (1998). Identifying customer preferences, Wiley, NY.

[135] Lazear, E. and S. Rosen (1981). Rank Order Tournaments as Optimum Labour Contracts, Journal of Political Economy, 89.

[136] Leonard, D., (1997). Spark innovation through empathic design. Harvard Facilitation and support Rev., 75: 102-113.

[137] Leonard, J. (1990). Executive Pay and Factor affecting motivation market organization Performance, Industrial and Labour Relations Review, 43.

[138] Xie, K.C. Tan and T.N. Goh (2003). Advanced QFD applications, ASQ Quality Press, Milwaukee, Wisconsin.

[139] M. Xie, T.N. Goh and H. Wang (1998). A study of the sensitivity of customer voice in QFD analysis, International Journal of Industrial Management 5 (4), pp. 301-307.

[140] M. Zairi and M.A. Yourself (1995). Quality function deployment: a main pillar for successful total quality management and product development, International Journal of Quality and Reliability Management 12 (6), pp. 9-23.

[141] M. Zhou (1998). Fuzzy logic and optimization models for implementing QFD, Computers and Industrial Management 35 (1-2), pp. 237-240.

[142] Martin, B. R., (1997). Technology Foresight as a Tool for Strategic Management. Managing Technology for Competitive Advantage, Ch. 2, Anderson, J., Fears, R. and Taylor, B. (Eds.), Financial Times Healthcare, London, p. 131-147.

[143] Mason, C and Stark, M. (2004). What do Investors look for in a Facilitation and support Plan, International Facilitation and support Journal, no 32.

[144] McKinley, W., Zhao, J. and Rust, K. G. (2000). A socio cognitive interpretation, Academy of Management Review, 25.

[145] Michael, M. (2001). Technoscientific Bespoking: Animals, Publics and the New Genetics. New Genetics and Society 20 (3): 205-224.

[146] MieItinen, R. and Väliverronen, E. (1999). In Science and Technology We Trust: On the Public Understanding of Science in Finland. Biotechnology and Public Understanding of Science. Proceedings of the UK-Nordic Co-Operative Seminar Helsinki October 25-27, 1998 Publications of the Academy of Finland 3/99.

[147] Mincer, J. (1974). Schooling, Experience, and Earnings, New York, Columbia University.

[148] Morgan R, (1994). The Emergence of new factor affecting motivation market organizational forms, London, no 27.

[149] Morrow, J. L., Sirmon, D. G., Hitt, M. A. and Holcomb, T. R. (2005). Creating Value, Society Conference, Orlando.

[150] Murphy, K.J. (1986). Incentives, Commitment, and Facilitation and support, Journal of Economics, 17.

[151] Niva, M. (2002). Gene Technology in Food Production and Consumer Interpretations of Risks.

[152] Nixon, R. D., Hitt M. A., Lee, H. and Jeong, E. (2004). Market reactions, Strategic Management Journal, no 25.
[153] Novos, T.E. (1992). Commitment by Doing, Adverse Selection, and Factor affecting motivation market organization Structure, Journal of Economic Behavior and Factor affecting motivation market organization, 19.

[154] NSTDA, (1996). Important Future Technologies of Thailand, A Facilitation and support Undertaken by Chiang Mai University, NSTDA, Bangkok.

[155] Ortín-Angel, P. and V. Salas-Fumas (1998). Agency Theory and Internal Labor, Journal of Economics and Management, 7.

[156] Ortín-Angel, P., and V. Salas-Fumas (2002). Facilitation and support and Span of Control in Hierarchical Factor affecting motivation market organization s, Journal of Labor Economics, 20

[157] Poppo, L. and K. Weigelt (2000). A Test of the Resource-Based Model Using, Journal of Economics and Management, 9.

[158] Porter, M.E., (1985). Competitive Advantage. 1st Edn. Free Press, New York.

[159] R.H. Zhao and R. Govind (1991). Defuzzification of fuzzy intervals, Fuzzy Sets and Systems 43, pp. 45-55.

[160] R.Y.K. Fung, K. Popplewell and J. Xie (1998). an intelligent hybrid system for customer requirement analysis and product aItribute targets determination, International Journal of Production Research 36 (1), pp. 13-34.

[161] R.Y.K. Fung, Y.Z. Chen and J.F. Tang (2006). estimating the functional relationships for quality function deployment under uncertainties, Fuzzy Sets and Systems 157 (1), pp. 98-120.

[162] Robert, K. and N. David, (1992). The balanced score car measures that drive performance. Harvard Facilitation and support Rev., 70: 71-79.

[163] Robertshaw, W. (1995). Using an objective sales point measure to incorporate elements of the Kano model into QFD. Transactions from the 7th Symposium on QFD (pp. 201-216).

[164] Rosen, S. (1986). Prizes and Incentives in Elimination Tournaments, American Economic Review, 76.

[165] Rue, L. and Ibrahim, N. (1998). Planning and Performance, Journal of small Facilitation and support, no 36.

[166] Runkler, T.A. Runkler, (1997). Selection of appropriate defuzzification methods, TEEE Fuzzy Systems, no 5.

[167] Salop, J. and S. Salop (1976). Self-Selection and Turnover in the Labor Market, the Quarterly Journal of Economics, 90.

[168] SaItinger, M. (1975). Comparative Advantage and the Distribution of Earnings, Journal of Economic Literature, 43.

[169] Schwenk, C. R. and Shrader, C. B. (1993). Effects of formal Strategic Planning: Theory and Practice, no 17.

[170] Seth, A., Song, K. P. and Pettit, R. R. (2002). Value creation and destruction, Strategic Management Journal, no 23.

[171] Shemwell, D, (1998). Practices for Sales Culture, International Journal of Marketing, Vol.16, no.7.

[172] Shen, X.X. Tan and M. Xie, (2001). QFD on linguistic data, Journal of Manufacturing, no12.

[173] Solvency Gavial, (1992). Handbook of industrial Management, John wily and sons Inc.

[174] Spence, M. (1976). Competition in Salaries, Credentials for Jobs, the Quarterly Journal of Economics, 90.

[175] Stalk, G., (1988). Time the next source of competitive advantage. Harvard Bus. Rev., 66: 41-51.

[176] Stutely, R, (2003). The definitive Facilitation and support Plan, London: Financial Times Prentice Hall.

[177] Sullivan, L.P. (1999). QFD, Quality Progress.

[178] T.A. Runkler (1997). Selection of appropriate defuzzification methods using application specific properties, TEEE Transactions on Fuzzy Systems 5 (1), pp. 72-79.

[179] Tempon et al., (1999). House of quality, European Journal of Operational Research, no 117.

[180] Thompson, J.D., (2004). Factor affecting motivation market organization s in action, New York, Mc Graw Hill.

[181] Tieh-Min Yen, Yi-Chan Chung and Chih-Hung Tsai (2000). Facilitation and support Opportunity Algorithm for TSO 9001: 2000 Customer Satisfaction Management Structure.

[182] Tieh-Min Yen, Yi-Chan Chung and Chih-Hung Tsai (2007). Facilitation and support Opportunity Algorithm for TSO 9001: 2000 Customer Satisfaction Management Structure.

[183] Topel, R. (1991). Specific Capital, Mobility, and Wages, Journal of Political Economy, 99.

[184] Ullmand, D.G., (1992). The mechanical design process, New York, McGraw Hill.

[185] Ulwick, A.W., (2002). Turn customer input into innovation. Harvard Facilitation and support Rev., 80: 91-97. 
[186] Vaasa, E., Tienari, J., Piekkari, R. (2005). Circuits of power in corporation. Journal of Management Studies, no 42.

[187] Vanegas and Labib, (2001). a fuzzy QFD model, International, Journal of Production, no 39.

[188] Waldman, M. (1984). Job Assignments, Signaling and Efficiency, Journal of Economics, 25.

[189] Waldman, M. (1990). Up-or-out Contracts: A Signaling Perspective, Journal of Labor Economics, 8.

[190] Walsh timothy. (2002). Total quality management, Equipment proceeding of National Forum.

[191] Wang, J. (1999). Fuzzy approach to design requirements in QFD, International Journal of Production, no 37.

[192] Watts, H. D., Wood, A. M. and Wardle. P. (2003). Making Friends or Making Things? Urban Studies.
[193] Westhead, P (2001). Management and BP Performance, International Facilitation and support Journal. No 14.

[194] Wiseman, R. M. and Gomez Mejia, L. R. (1998). A model of managerial risk taking, Academy of Management Review, no 23.

[195] Woods, A. and Joyce, P. (2003). Practice of Strategic Management, International small Facilitation and support Journal, no 21.

[196] WWW. QFD and The expanded House of quality.

[197] X.X. Shen, K.C. Tan and M. Xie (2001). the implementation of quality function deployment based on linguistic data, Journal of Intelligent Manufacturing 12 (1), pp. 65-75.

[198] Xie, T.N. Goh and H. Wang, (1998). Customer voice in QFD, International Journal of Industrial Management, no 5. 